\title{
Risiko Infrastruktur Jalan Tol dengan Skema Public- Private-Partnership (PPP) di ASEAN: Suatu Tinjauan Literatur
}

\author{
The Risk of Toll Road Infrastructure with Public-Private Partnership \\ (PPP) Scheme in ASEAN: A Literature Review
}

\author{
Erna Nurhayati $^{1, a)}$, Ersa Tri Wahyuni ${ }^{1, b)}$ \& Evita Puspitasari ${ }^{1, c)}$ \\ ${ }^{1)}$ Magister Akuntansi, Fakultas Ekonomi dan Bisnis, Universitas Padjadjaran, Bandung. \\ Koresponden : a)erna18001@mail.unpad.ac.id, ${ }^{\text {b) }}$ ersa@ unpad.ac.id \& \\ c)evita.puspitasari@unpad.ac.id
}

\begin{abstract}
ABSTRAK
Perkembangan pembangunan infrastruktur jalan tol dengan skema PPP semakin meningkat, meningkatnya kompleksitas permasalahan pada proyek PPP dijadikan objek riset yang menarik bagi kalangan akademisi/peneliti. Publikasi yang membahas risiko PPP jalan tol relatif meningkat setiap tahunnya, namun studi review literature dari paper yang ada belum tersedia. Studi ini menjawab kesenjangan ini dengan melakukan tunjauan literature review terhadap 75 artikel yang dijadikan sampel penelitian yang dipublikasikan dalam jurnal nasional/internasional selama rentang waktu 2010-2019. Artikel di review untuk mempelajari bagaimana tren penelitian dalam publikasi tahunan dari negara-negara di ASEAN, dan mengetahui risiko apasaja yang muncul dalam penelitian tersebut. Hasil penelitian menunjukkan adanya tren peningkatan publikasi, Indonesia mendominasi sebanyak 42 artikel (56\%) disusul Singapura dan Malaysia. Pendekatan kualitatif sebanyak 33 artikel (44\%) menjadi metodologi pilihan utama. Berdasarkan hasil literature didapat risiko yang sering diidentifikasi yaitu 10 faktor risiko yang paling banyak dilaporkan dalam literatur/ frekuensi tinggi adalah: Risiko Politik, Risiko Finansial, Risiko Desain, Konstruksi dan Uji Operasi, Risiko Operasi dan Pemeliharaan, Risiko Pendapatan, Risiko Force Majure, Risiko Lokasi, Risiko Kepemilikan Aset, Risiko Hubungan, dan Risiko Interface. Dominasi pembahasan mengenai identifikasi risiko pada artikel paling sering menjadi topik, sedangkan mengenai mitigasi risiko masih jarang dijumpai sehingga dapat menjadi topik riset bagi peneliti selanjutnya.
\end{abstract}

Kata Kunci : manajemen infrastruktur, risiko, Public-Private Partnership, jalan tol

\section{PENDAHULUAN}

Pembangunan infrastruktur sudah menjadi perhatian utama, baik di negara maju maupun di negara berkembang, diakui bahwa peningkatan infrastruktur sosial ekonomi dapat meningkatkan otonomi suatu negara. Peranan insfrastruktur dalam arti fisik seperti jaringan jalan harus dikelola sebagai aset fisik yang diharapkan dapat memenuhi kebutuhan masyarakat saat ini dan yang akan datang. Untuk mencapai hal tersebut, pemerintah terus berupaya meningkatkan penyediaan infrastruktur jalan tol dan melaksanakan penyediaan infrastruktur jalan tol bekerjasama dengan pihak swasta (investor, kontraktor, dan operator). Setiap infrastruktur memiliki lembaga atau badan pengelola yang bertanggung jawab (Suprayitno \& Soemitro, 2018). Pemenuhan infrastruktur sebagai aset memerlukan pengelolaan aset infrastruktur yang bertujuan untuk mendapatkan nilai atau "value" yang lebih besar dan 
mencapai tujuan utama pemiliknya (Debataraja et al., 2020). Bagi negara-negara berkembang dengan tingkat pertumbuhan ekonomi dan populasi yang cepat, Infrastruktur merupakan hal yang sangat penting. Setelah mengalami krisis di Asia pada tahun 1997/1998, sebagian besar negara di ASEAN kini menghadapi kekurangan pasokan infrastruktur yang memadai untuk mendukung pertumbuhan ekonomi yang cepat, dan tantangan untuk meningkatkan kualitas infrastruktur yang ada. Biaya yang sangat besar masih ditanggung oleh masing-masing negara hingga saat ini, pembangunan infrastruktur belum mendapat banyak perhatian, mengakibatkan kurangnya infrastruktur dasar seperti jalan, pelabuhan, jembatan, pembangkit listrik, instalasi air minum, dll.

Dibandingkan dengan kawasan lain di dunia, infrastruktur dasar di negara ASEAN masih tertinggal dari OECD, Amerika latin dan bahkan kawasan Asia lainnya (Emirullah \& Azam, 2014). Untuk memenuhi peningkatan permintaan layanan infrastruktur ini tentu membutuhkan sumber daya yang tidak sedikit. Menurut perkiraan Asian Development Bank (ADB), dana yang dibutuhkan ASEAN untuk mengatasi kekurangan infrastruktur mencapai 600.000 juta dolar untuk periode 2010-2020 (ADB, 2011). Keterbatasan anggaran pemerintah untuk membiayai pembangunan infrastruktur publik yang berpotensi menghabiskan biaya dan waktu pelaksanaan yang lama, hal ini menjadi tantangan besar dalam pembangunan infrastruktur.

Di sebagian besar negara, pemerintah bertanggung jawab untuk membiayai pembangunan infrastruktur (Kingombe, 2011). Infrastruktur publik sudah seharusnya disediakan oleh pemerintah untuk menjaga kompetisi dan stabilitas harga, namun ada risiko yang riskan terjadi. Untuk mengatasi tantangan pengadaan infrastruktur termasuk masalah hukum, sosial, politik dan keuangan, pemerintah telah mulai mengundang pihak swasta untuk bergabung dalam perjanjian kontrak jangka panjang melalui Public-private partnership (PPP) (Grimsey \& Lewis, 2005). PPP memungkinkan pemerintah mendapatkan keuntungan dari pihak swasta dalam mengelola dan mendanai layanan publik dan mengalihkan risiko kepada pihak swasta. Selain potensinya untuk memasok sumber daya yang diperlukan untuk investasi di bidang infrastruktur, PPP juga dianggap membawa manfaat tambahan, seperti peningkatan efisiensi dalam pembangunan proyek dan pengoperasian serta memungkinkan akses ke teknologi yang lebih maju. Sehingga, pemerintah dapat fokus pada pembuatan kebijakan, perencanaan dan regulasi. Pemikiran yang melibatkan dana swasta dalam pembiayaan infrastruktur publik adalah logis (Soemitro \& Suprayitno, 2020).

Skema PPP ini telah populer sejak awal 1990-an, dipimpin oleh Inggris dan negara maju lainnya seperti Jepang dan Australia. Sejak saat itu, pengaturan ini telah diadopsi di banyak belahan dunia, termasuk Amerika Serikat, Eropa Barat, Amerika latin, Australia, Asia Timur dan Selatan. PPP telah banyak digunakan secara global sebagai bentuk inovasi dalam berinvestasi guna memberikan layanan publik di industri konstruksi (Osei-Kyei \& Chan, 2017). Pemerintah di seluruh dunia telah banyak melibatkan sektor swasta untuk pembangunan infrastruktur karena terbatasnya anggaran publik (Glaister, 1999; Liu et al., 2015). Skema PPP telah banyak digunakan diberbagai sektor seperti sektor energi, telekomunikasi, transportasi, perumahan, rumah sakit, sumber daya air, dll (Cheung, E., \& Chan, A. P. 2011). Diantara semua sektor yang dibiayai dengan skema PPP paling banyak digunakan di sektor transportasi khususnya dalam pembangunan jembatan, rel kereta api, terowongan, bandara dan jalan tol (Kwak et al., 2009) dalam (Le et al., 2019). PPP dapat memberikan berbagai manfaat bagi pemerintah, namun pada dasarnya PPP juga memiliki kelemahan, tingkat risiko proyek PPP lebih tinggi dibandingkan dengan proyek lainnya. Menurut (Carbonara et al., 2015; Hwang et al., 2013) permasalahan risiko sangat penting pada proyek PPP, manajamen risiko sangat penting bagi para pemangku kepentingan untuk mencapai keberhasilan suatu proyek PPP.

Perkembangan pembangunan infrastruktur dengan skema PPP semakin meningkat di berbagai negara, meningkatnya kompleksitas permasalahan pada proyek PPP dijadikan objek riset menarik bagi kalangan akademisi dan para peneliti. Publikasi berupa artikel penelitian 
yang membahas mengenai risiko proyek jalan tol dengan skema PPP relatif meningkat setiap tahunnya. Sudah banyak literatur yang membahas mengenai risiko PPP. Beberapa penelitian membahas mengenai studi kasus, studi empiris baik kuantitatif maupun kualitatif, dan tinjauan literatur. Namun artikel-artikel tersebut berfokus pada kasus-kasus khusus, sektor air minum, dll. Sebagai contoh, penelitian mengenai Jaminan pendapatan dalam proyek PPP (Carbonara et al., 2014), penilaian risiko dan alokasi risiko dari perspektif investor di Indonesia (Santoso et al., 2012), faktor-faktor risiko proyek PPP di Malaysia (Alkaf, N., \& Karim, A, 2011). Hwang et al (2013) melakukan penelitian identifikasi risiko di Singapura. Dampak faktor risiko terhadap kinerja proyek transportasi kemitraan publik-swasta di Vietnam (Sy et al., 2016). Sebuah studi terbaru oleh Valipour et al (2019) penelitian mengenai risiko sektor air dan saluran pembuangan PPP di Malaysia (Valipour et al., 2019).

Dengan demikian, meskipun banyak literatur yang sudah dilakukan, namun studi review literature dari paper yang ada belum tersedia. Oleh karena itu penulis menganggap pentingnya penelitian ini dilakukan karena untuk menjawab kesenjangan ini dengan melakukan tinjauan literature review, dan juga alasan untuk memetakan evolusi keilmuan PPP dari tahun ke tahun, memberikan lansekap penelitian berikutnya untuk menghindari pengulangan, dan penting untuk mengeksplorasi penelitian saat ini dan tren penelitian masa depan (Tsai \& Lydia Wen, 2005). Alasan-alasan inilah yang kemudian mendorong penulis untuk melakukan penelitian Studi review literature mengenai risiko proyek jalan tol di ASEAN.

\section{KAJIAN PUSTAKA}

Proyek PPP biasanya memiliki tingkat risiko yang lebih tinggi daripada pengadaan konvensional, karena melibatkan banyak pemangku kepentingan, jumlah investasi yang besar dan periode konsesi yang panjang (Yang \& Dai, 2006) dalam (Carbonara et al., 2015). Oleh karena itu, proyek-proyek PPP tidak hanya melibatkan risiko yang terkait dengan proyek tetapi juga risiko yang bergantung pada karakteristik dalam PPP sebagai metode pengadaan. Manajemen risiko dalam proyek-proyek PPP yang dapat dikelompokkan sesuai dengan proses manajemen risiko konvensional, diantaranya: identifikasi risiko, analisis risiko, dan strategi/mitigasi risiko (Tang et al., 2010). Senada diungkapkan Pellegrino et al., (2010) meninjau literatur tentang identifikasi risiko dan kategorisasi dalam PPP dibagi menjadi dua kelompok: kelompok pertama terdiri dari studi yang berfokus pada sifat risiko, sedangkan yang kedua berisi yang berfokus pada fase proyek di mana risiko biasanya muncul (Pellegrino et al., 2013).

Telah banyak studi yang dilakukan mengenai masalah terkait risiko di negara ASEAN antara lain: Penelitian yang dilakukan oleh Alkaf, N., \& Karim, A. (2011) di Malaysia, hasil penelitian menunjukkan bahwa faktor frekuensi risiko tertinggi adalah perubahan hukum, keterlambatan persetujuan \& perijinan proyek dan pembebasan lahan. Faktor risiko dikelompokkan menjadi 10 kelompok yaitu risiko politik, konstruksi, hukum, ekonomi, opearasi, pasar, pemilihan proyek, keuangan proyek, hubungan dan faktor alam Alkaf, N., \& Karim, A, 2011). Li \& Zou (2011) mengelompokkan risiko yang berkaitan dengan jalan tol PPP proyek berdasarkan tahapan proyek secara berurutan seperti (i) perencanaan, (ii) tender, (iii) pembiayaan, desain, (iv) konstruksi, (v) operasi dan (vi) transfer karena penulis percaya klasifikasi ini merupakan hal yang umum untuk proyek KPS. Suseno et al (2015) melakukan wawancara dengan ahli BOT untuk mengidentifikasi risiko yang terkait dengan tol pasca konstruksi BOT jalan raya di Indonesia di mana mereka menetapkan kategori risiko di RBS, termasuk aspek keuangan, ekonomi aspek, rencana bisnis, aspek teknis dan force majeure (Suseno et al., 2015). Carbonara et al (2015) mensintesis pengetahuan dari penelitian sebelumnya untuk membuat daftar 22 risiko untuk sektor jalan raya dalam PPP (Carbonara et al., 2015). Adapun proyek PPP di Vietnam, Likhitruangsilp et al. (2017) mengklasifikasikan 33 faktor risiko yang diidentifikasi, faktor risiko dibagi menjadi dua kelompok utama: 1) Risiko 
umum, yang meliputi faktor risiko yang terkait dengan lingkungan proyek PPP. Kelompok risiko ini dibagi lagi menjadi kategori risiko politik, hukum, dan komersial. 2) Risiko khusus proyek, yang mencakup faktor risiko yang terkait dengan kinerja proyek PPP. Kelompok risiko ini dibagi lagi menjadi kategori desain dan pengadaan, konstruksi, dan operasi (Likhitruangsilp et al, 2017).

Publikasi ilmiah yang juga melakukan studi review literatur untuk risiko PPP juga dilakukan oleh Le, Kirytopoulos, Chileshe \& Rameezdeen (2019). Artikel ini memaparkan hasil analisis dari artikel-artikel yang terbit dalam search engine Scopus antara tahun 2008 sampai dengan tahun 2017. Risiko yang paling sering muncul adalah risiko volume lalu lintas, risiko biaya operasi dan pemeliharaan, risiko inflasi, risiko pembebasan lahan, risiko perubahan hukum dan peraturan, risiko tariff (Le et al., 2019). Hasil penelitian Mohd-Rahim, Abd-Rahim, Zainon, Chuing \& Abd-Samad (2018) adalah sebagai berikut: dari 59 faktor risiko yang teridentifikasi, 8 risiko dialokasikan ke sektor publik dan 40 faktor risiko dialokasikan kepada pihak swasta. Kemudian Ada 11 faktor risiko di alokasikan ke kedua belah pihak.

\section{METODOLOGI PENELITIAN}

Metode penelitian yang digunakan adalah metode kualitatif dengan pendekatan tematik reviu literatur terstruktur (Tranfield et al., 2003; Durach et al, 2017). Metode riset disusun berdasarkan pertanyaan riset sebagai berikut:

1. Bagaimana tren penelitian mengenai risiko proyek jalan tol dengan skema Public-private partnership (PPP) di ASEAN pada rentang waktu 2010-2019?

2. Risiko apasaja yang teridentifikasi dalam penelitian tersebut?

Teknik pengambilan sampel menggunakan nonprobability sampling dengan teknik sampling sistematis. Sampel penelitian yang diambil berdasarkan kriteria sebagai berikut:

1. Proses pencarian artikel penelitian dengan menggunakan search engine: Science Direct, Emerald Insight, EBSCO Host, Wiley online library, Research Gate, Garuda, Sinta dan Google Scholar, proses penelusuran dilakukan pada bulan Juli 2020.

2. Penelusuran artikel penelitian dilakukan dengan menggunakan kata kunci: Public-private partnerships/ PPP/ P3/ Kerjasama Pemerintah dan Badan Usaha/ Kerjasama pemerintah swasta/ KPBU/ KPS/ Risk/ Risiko, Toll Road/Tollway/ Highway/ Jalan tol.

Dalam penelitian ini proses analisis data yang akan dilakukan oleh peneliti sebagai berikut :

1. Mempersiapkan artikel-artikel penelitian yang sesuai dengan kata kunci pencarian

2. Memilih artikel yang sesuai dengan langkah-langkah sebagai berikut:

1) Tahun publikasi 2010 hingga 2019

2) Pengambilan sampel dari berbagai sitasi berbeda sehingga ada kemungkinan artikel yang sama terdaftar di berbagai tempat. Oleh karena itu, artikel yang terduplikasi pada sitasi lain harus dikeluarkan dari sampel

3) Jika ditemukan tulisan yang bukan berupa artikel penelitian seperti skripsi, thesis, artikel skripsi, atau makalah serta artikel yang tidak terpublikasi harus dikeluarkan dari sampel

4) Artikel yang menjadi sampel harus merupakan artikel yang bahasan utamanya mengenai risiko proyek jalan tol dengan skema PPP dan pengambilan sampel di ASEAN, sehingga artikel yang pembahasannya di luar tema tersebut harus dikeluarkan dari sampel

5) Untuk menjaga kualitas dan validitas artikel yang dijadikan sampel, maka dipilih artikel-artikel yang bereputasi internasional ataupun nasional, artikel tersebut terindeks scopus (Q1-Q4) atau terakreditasi dikti (S1-S4) dengan memperhatikan jumlah sitasi pada masing-masing paper tersebut. Jika syarat tersebut tidak dipenuhi maka artikel dikeluarkan dari sampel penelitian. 
6) Kemudian dilakukan pengecekan kelengkapan data. Jika tidak mendapatkan artikel utuh atau hanya ada abstrak, maka dikeluarkan dari sampel.

3. Mengklasifikasikan riset berdasarkan:

1) Tahun publikasi

2) Negara asal terbit jurnal

3) Metode penelitian

4) Unit analisis

5) Pendekatan penelitian

Awalnya didapat hasil pencarian sebanyak 4.307 artikel, kemudian dilakukan kembali proses penyaringan berdasarkan kriteria inklusi dan eksklusi, oleh karena itu artikel diperiksa secara singkat dengan membaca abstrak dan kesimpulan untuk menyaring artikel yang benarbenar relevan. Sebanyak 75 artikel dipilih untuk dianalisa lebih lanjut. Ukuran sampel ini cukup dapat memberikan gambaran yang baik dibandingkan dengan studi review literatur yang dilakukan sebelumnya dimana Yu et al (2018) mengulas 37 makalah tentang Critical Risk Factor pada Transnational PPP Project (Yu et al., 2018), penelitian lainnya yang dilakukan (Osei-Kyei \& Chan, 2015) tentang faktor penentu keberhasilan PPP mengulas 27 artikel. Tabel 1 merangkum jumlah makalah yang relevan di identifikasi berdasarkan kriteria inklusi dan ekslusi.

Tabel 1. Tabel Pencarian Artikel Relevan

\begin{tabular}{|c|l|r|r|r|}
\hline No & \multicolumn{1}{|c|}{ Sumber } & Hasil & $\begin{array}{c}\text { Artikel Tidak } \\
\text { Relevan }\end{array}$ & $\begin{array}{c}\text { Artikel } \\
\text { Relevan }\end{array}$ \\
\hline 1 & Science direct & 391 & 384 & 7 \\
\hline 2 & Emerald insight & 272 & 268 & 4 \\
\hline 3 & EBSCO Host & 133 & 128 & 5 \\
\hline 4 & Wiley Online Library & 58 & 58 & 0 \\
\hline 5 & Research Gate & 120 & 96 & 24 \\
\hline 6 & Garuda & 893 & 871 & 22 \\
\hline 7 & Sinta & 14 & 13 & 1 \\
\hline 8 & Google Scholar & 2,426 & 2,414 & 12 \\
\hline & Total & 4,307 & 4,232 & 75 \\
\hline
\end{tabular}

\section{HASIL DAN ANALISA}

\section{Tren Penelitian Rentang Waktu 2010-2019}

Terkait dengan pertanyaan riset pertama, artikel penelitian mengenai risiko proyek jalan tol dengan skema Public-private partnership di ASEAN sudah banyak ditemukan. Setelah diperoleh sejumlah sampel yang memenuhi persyaratan yang ditentukan, artikel-artikel penelitian tersebut kemudian dianalisis secara manual dan rinci untuk mengekstrak berbagai informasi yang tidak bisa diperoleh secara langsung hanya dengan melihat judul artikel. Untuk melakukannya dilakukan pemeriksaan pada abstrak, pembahasan dan kesimpulan pada tiaptiap artikel penelitian.

Kajian ini memanfaatkan beberapa artikel dari 8 search engine. Penggunaan search engine yang berbeda untuk melengkapi satu sistem dengan sistem lainnya. Catatan penting yang bisa disampaikan adalah, dibandingkan search engine lainnya Science direct menawarkan kemudahan terbaik bagi penggunanya untuk mendapatkan artikel sesuai dengan kebutuhan dengan fleksibilitas fitur pencarian yang dimilikinya. Menggunakan search engine yang tersedia dalam sistem dihasilkan 75 artikel yang relevan dapat dijadikan sampel penelitian. 
Hasil pembagian artikel berdasarkan negara yang menjadi objek penelitian dalam kurun waktu tahun 2010-2019 disajikan pada Gambar 1 menyajikan jumlah artikel yang relevan berdasarkan lokasi data yang di kumpulkan. Secara total ada 6 dari 9 negara di ASEAN ditemukan yang menjadi objek penelitian para peneliti. Indonesia mendominasi $56 \%$ atau sebanyak 42 artikel penelitian, diikuti Singapore 14,67\% (11 artikel), Malaysia 14,67\% (11 artikel), Vietnam 10,67\% (8 artikel), Thailand 2,67\% (2 artikel) dan Philippina 1,33\% (1 artikel). Riset tentang risiko jalan tol di ASEAN dengan skema PPP hanya terkonsentrasi pada negara-negara tertentu saja. Mengetahui jumlah penelitian di masing-masing negara dapat memberikan wawasan berguna dimana dapat dilihat sejauh mana inisiatif manajamen risiko pada proyek tol di masing-masing negara ASEAN.

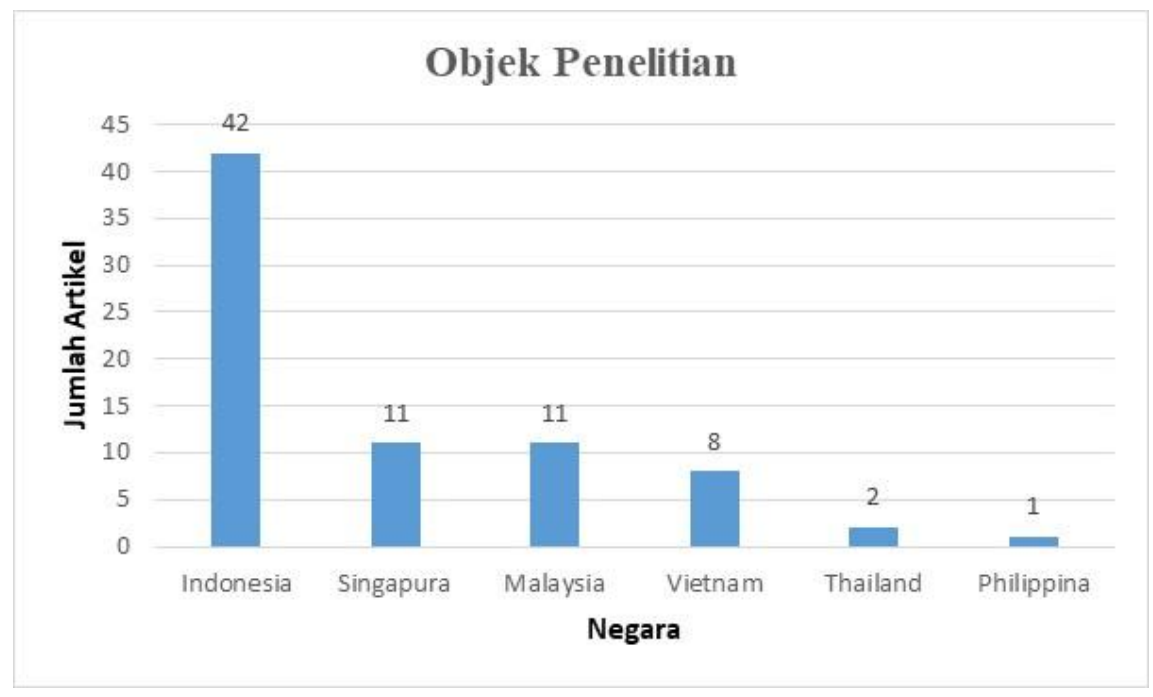

Gambar 1. Pembagian Artikel Berdasarkan Negara Penelitian

Publikasi berupa artikel yang membahas mengenai risiko proyek jalan tol dengan skema Public-private partnership di ASEAN relatif meningkat setiap tahunnya. Gambar 2 menyajikan sebaran jumlah artikel relevan yang dipublikasikan selama kurun waktu 2010-2019. Seperti terlihat, artikel risiko dalam proyek jalan tol di ASEAN berfluktuasi dari tahun ke tahun, artinya minat dalam topik ini tidak menunjukkan tren kenaikan atau penurunan tertentu, tidak ada suatu tren khusus yang bisa diamati. Jumlah artikel meningkat dan sempat mencapai puncaknya pada tahun 2017 sebanyak 12 artikel terpublikasi, diikuti oleh 11 artikel pada tahun 2019. Tren penelitian mengenai risiko PPP diprokyesikan akan terus meningkat karena akan lebih banyak proyek dikembangkan di seluruh dunia (Osei-Kyei \& Chan, 2015).

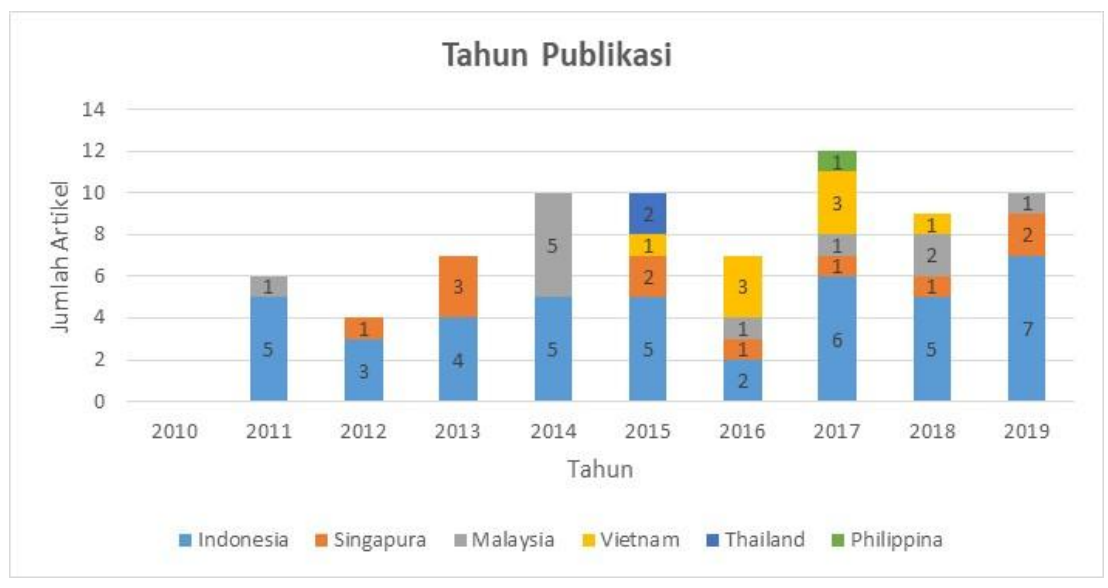

Gambar 2. Pembagian Artikel Berdasarkan Tahun Publikasi 
Hasil pembagian artikel berdasarkan jurnal yang diterbitkan Internasional atau Nasional disajikan pada Gambar 3. Artikel yang diterbitkan dari jurnal Internasional sebanyak 50 artikel. Sedangkan artikel yang diterbitkan dari jurnal nasional sebanyak 25 artikel. Terdiri dari jurnal yang bereputasi internasional dan nasional sebanyak 38 artikel terdiri dari: 25 jurnal memiliki reputasi internasional yang tinggi (Q1-Q4) dan 13 jurnal memiliki reputasi nasional (S1-S4) dan 37 artikel yang ber ISSN.

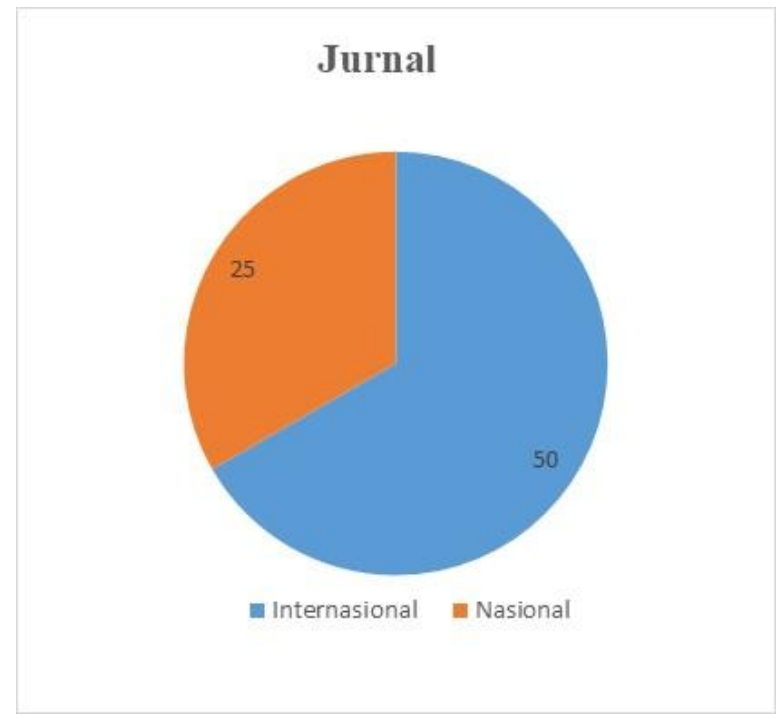

Gambar 3. Pembagian Artikel Berdasarkan Asal terbit Jurnal

Masih berdasarkan analisis konten artikel yang dievaluasi, dari 75 artikel sebanyak 33 artikel (44\%) menggunakan pendekatan kualitatif, 29 artikel kuantitatif $(38,67 \%)$ dan sisanya 13 artikel (17,33\%) menggunakan pendekatan kualitatif-kuantitatif. Gambar 4 menunjukkan distribusi artikel yang menggunakan ketiga pendekatan riset ini berdasarkan negara-negara yg menjadi objek penelitian. Metode riset kualitatif mendominasi di negara Singapura, Malaysia, Thailand dan Philipina. Sedangkan Indonesia di dominasi metode kuantitatif.

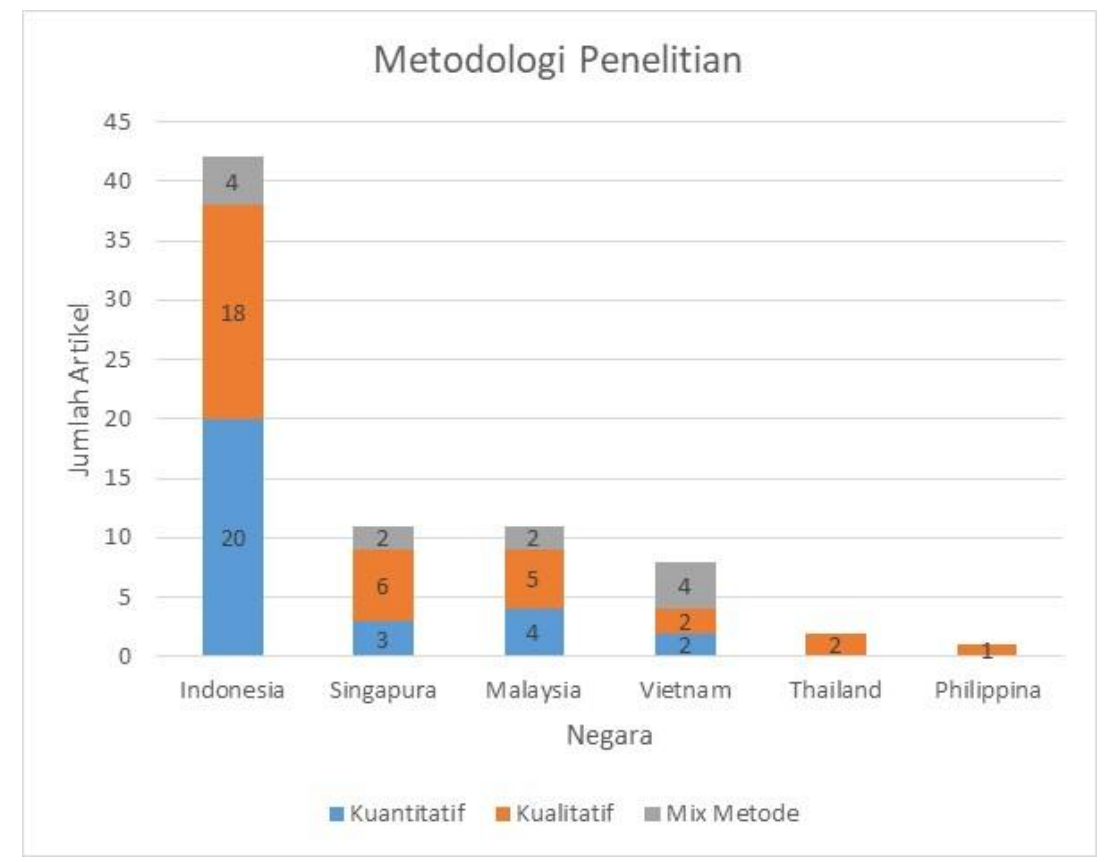

Gambar 4. Pembagian Artikel Berdasarkan Metodologi Penelitian 
Artikel dianalisis lebih lanjut untuk menjelaskan metodologi penelitian yang digunakan pada masing-masing artikel. Gambar 5 menunjukan metode riset berdasarkan artikel terseleksi. Hasilnya menunjukkan bahwa metode yang digunakan dalam artikel penelitian sangat beragam, mulai dari Analysis/ conceptual method, Secondary data analysis/library/ research/literature, Survey/ Questionare, Case Study, sampai Content analysis. Jumlah metode memang melebihi jumlah artikel karena dalam satu artikel bisa digunakan lebih dari satu metode. Sebagai contoh (Chou \& Pramudawardhani, 2015) dan (Sy et al., 2016) mengkombinasikan Survey/ Questionare dan Secondary data analysis/libraryresearch/literature. Survey/ Questionare metode yang cukup mendominasi digunakan dalam metode penelitian, total 25 artikel yang menggunakan metode ini. Setiap metode memiliki kelebihan dan kekurangan masing-masing, tergantung pada masalah latar belakang penelitian, ruang lingkup dan waktu.

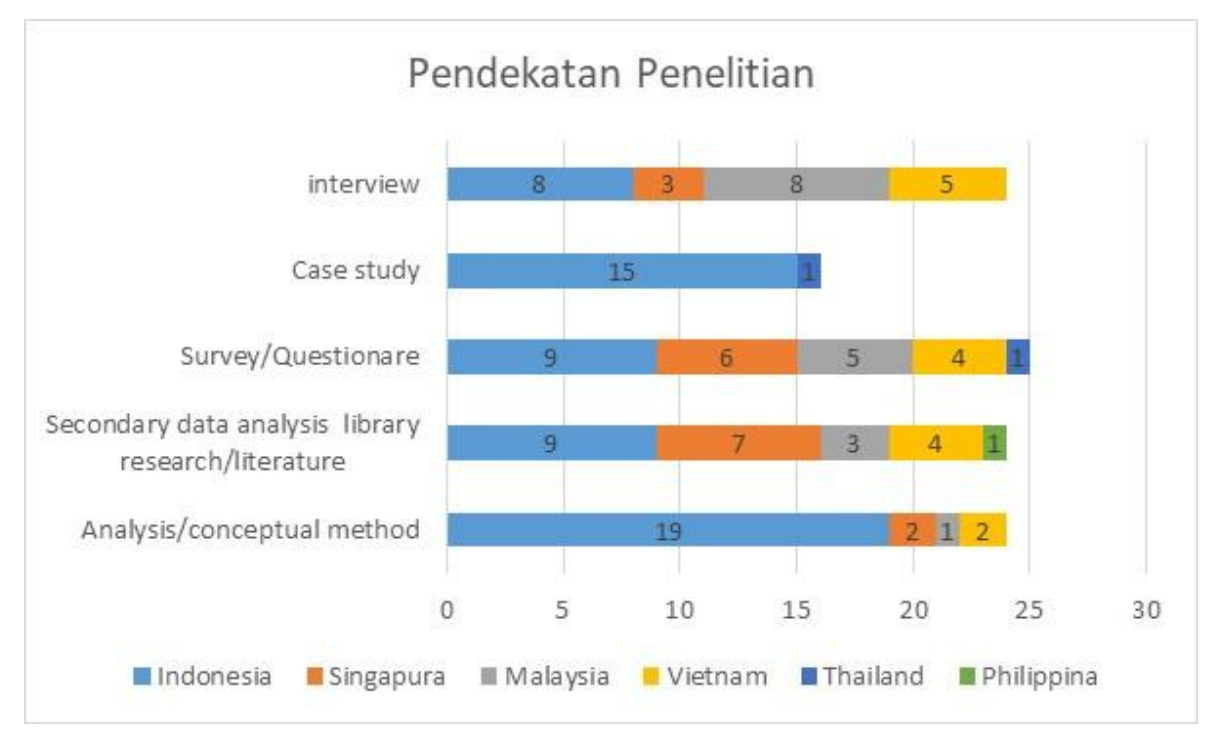

Gambar 5. Pembagian artikel berdasarkan pendekatan penelitian

\section{Risiko-Risiko Temuan Dalam Artikel}

Manajamen risiko merupakan topik penting dalam penelitian PPP (Ke et al., 2009). Dalam studi literatur review ini, proses manajemen risiko dibagi menjadi Risk Identification, Risk Assessment, Risk Allocation dan Risk Mitigation. Dari 75 artikel yang dievaluasi, sebanyak 54,63\% (59 artikel) difokuskan pada identifikasi risiko, 22,22\% (24 artikel) pada analisis risiko, $15,74 \%$ (17 artikel) pada alokasi risiko, 7,41\% (8 artikel) pada mitigasi risiko. Jumlah area riset memang melebihi jumlah artikel karena dalam satu artikel bisa membahas lebih dari satu area riset. Gambar 6 memperlihatkan distribusi jumlah artikel berdasarkan area riset. Dominasi pembahasan identifikasi risiko pada artikel yang paling sering menjadi topik pembahasan. Gambar 7 memperlihatkan sebaran area riset manajamen risiko di masing-masing negara penelitian. 


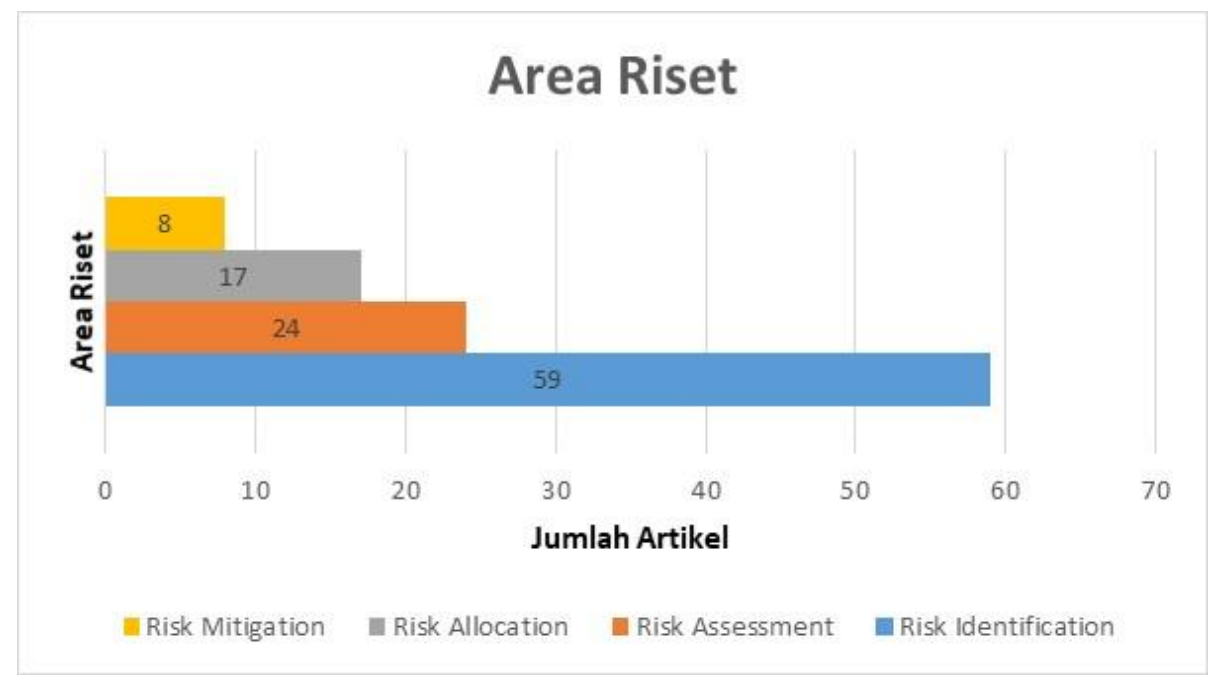

Gambar 6. Pembagian Artikel Berdasakan Area Riset

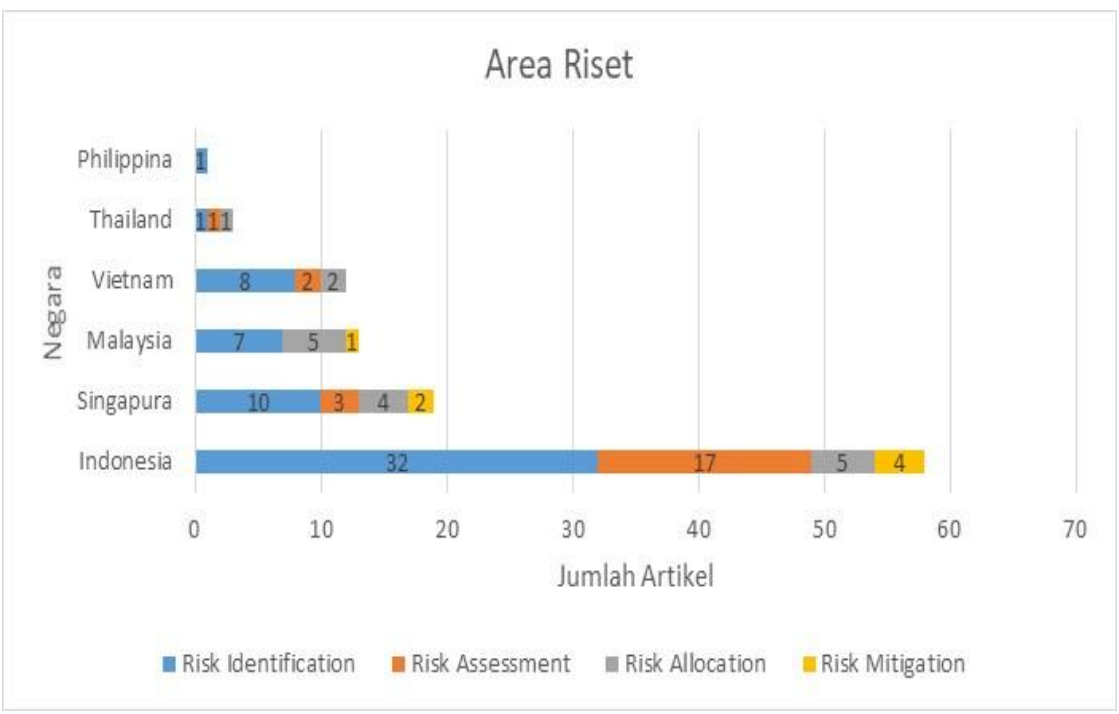

Gambar 7. Pembagian Artikel Berdasakan Area Riset di Masing-Masing Negara

Dari 75 artikel yang dianalisis, sebanyak 12 risiko teridentifikasi dalam artikel penelitian, kemudian 12 risiko tersebut membahas masing-masing faktor risiko ada sebanyak 105 faktor risiko ditemukan. Tabel 2 merangkum kelompok faktor dan faktor risiko teridentifikasi. 
Tabel 2. Risiko dan Faktor Risiko Teridentifikasi

\begin{tabular}{|c|c|c|c|}
\hline No & $\begin{array}{c}\text { Kelompok } \\
\text { Faktor }\end{array}$ & Faktor Risiko & Jumlah \\
\hline 1 & Risiko Lokasi & $\begin{array}{l}\text { Pembebasan Lahan, Risiko Status Tanah, } \\
\text { Keterlambatan dan Kenaikan Biaya Pembebasan } \\
\text { Lahan }\end{array}$ & 3 \\
\hline 2 & $\begin{array}{l}\text { Risiko Desain, } \\
\text { Konstruksi dan } \\
\text { Uji Operasi }\end{array}$ & $\begin{array}{l}\text { Kesalahan Desain, Kenaikan Biaya Konstruksi, } \\
\text { Risiko Konstruksi, Studi Kelayakan Proyek, } \\
\text { Perubahan Lingkup Pekerjaan Pasca } \\
\text { Penandatanganan Kontrak, Gagal Menjaga } \\
\text { Keamanan dan Keselamatan Dalam Lokasi, } \\
\text { Terlambatnya Penyelesaian Konstruksi, Risiko Uji } \\
\text { Operasi, Ketidakjelasan Spesifikasi Output, } \\
\text { Kinerja Kontraktor/sub kontraktor yang buruk, } \\
\text { Risiko Tekni, Risiko Proyek, Manajemen Kontrak } \\
\text { yang baru, Kegagalan Uji Komisioning, } \\
\text { Ketersediaan Terbatas dan Keandalan Pemasok, } \\
\text { Resistensi dari pemangku kepentingan / klien } \\
\text { untuk mengadopsi ide, Permintaan khusus dari } \\
\text { klien tentang teknologi yang akan digunakan, } \\
\text { Penundaan disebabkan oleh seringnya pertemuan } \\
\text { dengan spesialis, Masalah penyelesaian, Kapasitas } \\
\text { SPV rendah }\end{array}$ & 20 \\
\hline 3 & Risiko Sponsor & Default sponsor proyek, Default Lender Proyek & 2 \\
\hline 4 & Risiko Finansial & $\begin{array}{l}\text { Risiko tingkat inflasi, Risiko tingkat suku bunga, } \\
\text { Ketersediaan keuangan, Risiko keuangan, Pasar } \\
\text { keuangan yang buruk, Risiko ekonomi, Daya tarik } \\
\text { finansial proyek bagi investor, Risiko nilai tukar } \\
\text { mata uang, Permintaan pasar berubah, Biaya } \\
\text { keuangan tinggi, Peristiwa ekonomi yang } \\
\text { berpengaruh, Kegagalan mencapai financial close, } \\
\text { Risiko keterlambatan dukungan pemerintah, Aliran } \\
\text { dana pelaksanaan proyek dari manajemen, Risiko } \\
\text { asuransi, Terjadinya kenaikan harga BBM selama } \\
\text { proyek pembangunan jalan tol berlangsung, } \\
\text { keuangan kontraktor tidak lancar, Kemungkinan } \\
\text { tidak disetujui oleh kementerian keuangan, Proses } \\
\text { persetujuan di kementerian keuangan memakan } \\
\text { waktu lama, Pembatasan bea cukai dan impor }\end{array}$ & 19 \\
\hline
\end{tabular}


Tabel 2. (Lanjutan)

\begin{tabular}{|c|c|c|c|}
\hline No & $\begin{array}{l}\text { Kelompok } \\
\text { Faktor }\end{array}$ & Faktor Risiko & Jumlah \\
\hline 5 & Risiko Operasi & $\begin{array}{l}\text { Kenaikan biaya O\&M, Ketersediaan fasilitas } \\
\text { (bahan/tenaga kerja), Risiko sosial dan budaya } \\
\text { lokal, Biaya perawatan lebih tinggi dari yang } \\
\text { diharapkan, Buruk atau tidak tersedianya layanan, } \\
\text { Kesalahan estimasi biaya life cycle, Produktivitas } \\
\text { pengoperasian rendah, Risiko tenaga kerja, Nilai } \\
\text { sisa (setelah masa konsesi)/ nilai transfer sisa, } \\
\text { Kegagalan kontrol dan monitoring proyek, } \\
\text { Kegagalan manajamen proyek, Pengalaman yang } \\
\text { tidak memadai di PPP, Penundaan persetujuan } \\
\text { dalam periode operasi, }\end{array}$ & 13 \\
\hline 6 & $\begin{array}{l}\text { Risiko } \\
\text { Pendapatan }\end{array}$ & $\begin{array}{l}\text { Risiko volume dan tingkat pertumbuhan lalu lintas, } \\
\text { Kesalahan perhitungan estimasi tarif/ Perubahan } \\
\text { tarif tol, Pendapatan operasional di bawah } \\
\text { ekspektasi, Kegagalan pembayaran AP secara } \\
\text { tepat waktu, Kewajiban ganti rugi pihak ketiga, } \\
\text { Kegagalan mengajukan penyesuaian tarif }\end{array}$ & 6 \\
\hline 7 & $\begin{array}{l}\text { Risiko } \\
\text { Konektivitas } \\
\text { Jaringan } \\
\end{array}$ & $\begin{array}{l}\text { Kurangnya keahlian konsorsium, Risiko fasilitas } \\
\text { pesaing/ kompetitor }\end{array}$ & 2 \\
\hline 8 & Risiko Interface & $\begin{array}{l}\text { Risiko ketimpangan waktu dan kualitas pekerjaan, } \\
\text { Risiko perbedaan standar/teknik, Evaluasi } \\
\text { subyektif }\end{array}$ & 3 \\
\hline 9 & Risiko Politik & $\begin{array}{l}\text { Perubahan regulasi umum (UU/ kebijakan), } \\
\text { Gagal/terlambatnya perolehan persetujuan dan } \\
\text { perijinan, Perubahan regulasi spesifik } \\
\text { (perpajakan), Korupsi dan penyuapan, } \\
\text { Pemerintah tidak stabil, Kurangnya kerangka } \\
\text { hukum / peraturan, Kurangnya } \\
\text { dukungan/komitmen dari pemerintah/ swasta, } \\
\text { Nasionalisasi aset, Risiko organisasi dan } \\
\text { koordinasi, Oposisi / permusuhan politik yang } \\
\text { kuat, Pelanggaran kontrak (yaitu klaim dan } \\
\text { perselisihan), Proses pengambilan keputusan } \\
\text { publik yang buruk, Variasi kontrak yang } \\
\text { berlebihan, Sistem hukum yang belum matang, } \\
\text { Penghentian konsesi oleh pemerintah, Perubahan } \\
\text { regulasi industri, Campur tangan politik yang kuat, } \\
\text { perubahan struktur pemerintahan, Keterlambatan } \\
\text { perolehan persetujuan perencanaan, Permusuhan } \\
\text { politik yang kuat, Penundaan pihak ketiga, } \\
\text { Sengketa kontrak }\end{array}$ & 22 \\
\hline
\end{tabular}


Tabel 2. (Lanjutan)

\begin{tabular}{|c|l|l|c|}
\hline No & $\begin{array}{c}\text { Kelompok } \\
\text { Faktor }\end{array}$ & \multicolumn{1}{|c|}{ Faktor Risiko } & Jumlah \\
\hline 11 & $\begin{array}{l}\text { Risiko } \\
\text { Kepemilikan } \\
\text { Aset }\end{array}$ & $\begin{array}{l}\text { Risiko Aset Sisa, Tingkat permintaan proyek, } \\
\text { Transfer aset setelah kontrak berakhir, Risiko } \\
\text { persaingan, Risiko nilai aset turun, Tender tidak } \\
\text { kompetitif, Ketidakmampuan pemegang ijin konsesi, } \\
\text { Perubahan kepemilikan }\end{array}$ & 8 \\
\hline 12 & $\begin{array}{l}\text { Risiko } \\
\text { Hubungan }\end{array}$ & $\begin{array}{l}\text { Distribusi tanggung jawab dan risiko yang tidak } \\
\text { memadai, Perbedaan dalam metode kerja dan } \\
\text { pengetahuan antara mitra, Distribusi kewenangan } \\
\text { yang tidak memadai dalam kemitraan }\end{array}$ & 3 \\
\hline & \multicolumn{1}{|c|}{ Total } & $\mathbf{1 0 5}$ \\
\hline
\end{tabular}

\section{PEMBAHASAN}

Hasil analisa juga menunjukkan bahwa 10 faktor risiko yang paling banyak dilaporkan dalam literatur/ frekuensi tinggi adalah: Risiko Politik, Risiko Finansial, Risiko Desain, Konstruksi dan Uji Operasi, Risiko Operasi dan Pemeliharaan, Risiko Pendapatan, Risiko Force Majure, Risiko Lokasi, Risiko Kepemilikan Aset, Risiko Hubungan, dan Risiko Interface. Hasilnya menunjukkan bahwa ini adalah risiko paling signifikan dalam proyek jalan tol dengan skema PPP di ASEAN. Dari 10 faktor risiko yang teridentidikasi paling banyak dibahas dalam artikel, dengan mempertimbangkan keterbatasan ruang dalam tulisan ini, maka hanya 5 risiko yang dibahas secara rinci, yaitu sebagai berikut.

\section{Risiko Politik}

Dalam 75 artikel yang diidentifikasi, risiko politik paling banyak dijumpai dalam artikelartikel penelitian, risiko politik dijabarkan kembali kedalam 22 faktor risiko. hasil penelitian Alkaf \& Karim (2011) di Malaysia menyatakan bahwa identifikasi faktor-faktor risiko dikelompokkan menjadi 10 kelompok yaitu: Politik, Konstruksi, Hukum, Ekonomi, Operasi, Pasar, Pemilihan proyek, Keuangan proyek, Hubungan, dan Faktor alam. Hasilnya menunjukkan bahwa faktor frekuensi skor tertinggi adalah perubahan dalam hukum, keterlambatan dalam persetujuan \& izin proyek dan pembebasan lahan (Alkaf \& Karim, 2011). Campur tangan politik dalam proses pengadaan, politik ingkar selama itu periode, penarikan jaringan dukungan pemerintah, penghentian konsesi oleh pemerintah, pencabutan, pengambilalihan, sekuestrasi, dan peristiwa force majeure politik semuanya potensial risiko politik (Chou \& Pramudawardhani, 2015); Dukungan politik sangat penting dalam pelaksanaan kontrak PPP. Selanjutnya di proyek jalan tol, investor swasta melakukan bisnis di sektor yang sensitif secara politik dengan pemerintah yang kuat; jadi mereka membutuhkan dukungan politik yang sehat dan legal untuk memastikan keadilan, transparansi, dan keberlanjutan jangka panjang (Wibowo \& Alfen, 2015).

\section{Risiko Finansial}

Risiko tingkat inflasi diidentifikasi dalam 26 artikel berbeda. Le et al (2019) menyebutkan dalam penelitiannya bahwa Risiko yang paling sering disebutkan adalah Fluktuasi tingkat inflasi $(3,80 \%)$, Perubahan hukum dan peraturan '(3,33\%), Fluktuasi suku bunga $(3,33 \%)$. Inflasi didefinisikan sebagai Kenaikan tingkat harga komoditas, penurunan pembelian kekuatan mata uang, yang menyebabkan peningkatan biaya dan konsekuensi lainnya (Le et al., 2019). Mereka mengidentifikasi 16 risiko dasar dan mereka menunjukkan bahwa risiko pembentukan, inflasi dan perubahan harga lebih penting daripada yang lain (Chan et al., 2011). Inflasi dan 
perubahan suku bunga serta kegagalan untuk memenuhi risiko royalti pemerintah memiliki pengaruh yang paling besar (Mehrizi \& Bafqi, 2016). Daya tarik proyek, yang dapat dikaitkan dengan yang diharapkan manfaat, juga mempengaruhi aksesibilitas dan ketersediaan pembiayaan (Chou \& Pramudawardhani, 2015).

\section{Risiko Desain, Konstruksi dan Uji Operasi}

Risiko kesalahan desain diidentifikasi dalam 25 artikel. Abdullah (2014) dalam penelitiannya menyatakan jika ada kesalahan dalam desain, konsultan desain akan bertanggung jawab atas kerugian yang mereka coba kurangi dengan membeli polis Asuransi Ganti Rugi Profesional (Abdullah et al., 2014). Hasil temuan menunjukkan adanya beberapa bentuk manajemen risiko dalam proyek PPP dimana kesepakatan dan konsep desain memiliki peran yang sangat penting dalam pengelolaan risiko (Ahmad et al., 2018). Sektor swasta harus lebih memahami risiko desain dan konstruksi, termasuk kekurangan desain, kelebihan biaya konstruksi, penundaan waktu konstruksi, ketersediaan material. Oleh karena itu tidak mengherankan jika lebih baik dialokasikan kepada sektor swasta (Hwang et al., 2013). Nguyen (2018) dalam penelitiannya di Vietnam menyebutkan, temuan menunjukkan bahwa kondisi geografis yang tidak terduga dapat mengakibatkan perubahan desain yang diminta oleh pemerintah. Risiko ini juga dapat menyebabkan pembengkakan biaya konstruksi. Ini menyiratkan kemungkinan efek interaktif di antara berbagai faktor risiko (Nguyen et al., 2018).

\section{Risiko Pendapatan}

Risiko pendapatan terdiri dari 6 faktor risiko yaitu: Risiko volume dan tingkat pertumbuhan lalu lintas, Kesalahan perhitungan estimasi tarif/ Perubahan tarif tol, Pendapatan operasional di bawah ekspektasi, Kegagalan pembayaran AP secara tepat waktu, Kewajiban ganti rugi pihak ketiga, Kegagalan mengajukan penyesuaian tarif.

Risiko volume lalu lintas diidentifikasi dalam 25 artikel. Persepsi risiko pemangku kepentingan dalam pengaturan kontrak tertentu di sektor jalan di mana risiko lalu lintas sering kali menjadi risiko utama, dan ini dapat membatasi sejauh mana temuan dapat digeneralisasikan (Chung \& Hensher, 2015). Faktor signifikannya adalah perubahan tarif. Ini terjadi ketika desain tarif yang tidak tepat atau kerangka penyesuaian yang tidak fleksibel yang menyebabkan pendapatan tidak mencukupi (Alkaf, N., \& Karim, A, 2011)

\section{Risiko Lokasi}

Risiko pembebasan lahan merupakan risiko yang cukup banyak dibahas, terdapat 30 artikel berbeda yang membahasnya. Santoso et al., (2012) Mengenai Penilaian Risiko dan Alokasi dari perspektif investor untuk jalan tol PPP yang sudah konstruksi dan beroperasi, hasilnya Risiko yang terkait dengan pembebasan lahan diidentifikasi sebagai peristiwa risiko utama dalam proyek jalan tol Indonesia. Risiko cuaca harus dibagi oleh kedua belah pihak dengan risiko yang tersisa ditanggung oleh investor (S. Santoso et al., 2012); Pembebasan lahan dalam proyek jalan raya selalu diidentifikasi sebagai risiko proyek yang paling efektif. Karena tidak adanya akuisisi yang tepat waktu menyebabkan keterlambatan dalam proses eksekutif, dan tidak hanya meningkatkan biaya dan waktu pembangunan, tetapi juga berpengaruh pada durasi kontrak, dan beberapa klaim oleh pihak swasta (Mehrizi \& Bafqi, 2016); Risiko yang paling sensitif adalah Ketersediaan lahan, Proses ganti rugi, Penolakan Masyarakat, banyaknya calo tanah, dan sumber pendanaan yang belum jelas (Sandhyavitri \& Saputra, 2019); Selanjutnya pada investasi proyek jalan tol, risiko tertinggi adalah pembebasan lahan. Sebelum menyelesaikannya, pembangunan tidak dapat dimulai (Sihombing, 2017). 


\section{KESIMPULAN}

Studi review literatur yang dilakukan dalam tulisan ini merupakan risiko proyek jalan tol dengan skema PPP di ASEAN. Paper yang dijadikan sampel adalah paper yang memenuhi kriteria kata kunci pencarian. Hasil yang didapatkan sejumlah 75 Artikel sampel hasil seleksi selama kurun waktu 2010-2019, dapat disimpulkan sebagai berikut :

1. Hasil pembagian artikel berdasarkan negara yang menjadi objek penelitian dalam kurun waktu tahun 2010-2019 menyajikan jumlah artikel yang relevan berdasarkan lokasi data yang dikumpulkan. Secara total ada 6 dari 9 negara di ASEAN di temukan yang menjadi objek penelitian para peneliti. Indonesia mendominasi sebanyak 42 artikel (56\%) disusul Singapura dan Malaysia.

2. Hasil penelitian ini menunjukkan adanya tren peningkatan publikasi. Jumlah artikel meningkat dan sempat mencapai puncaknya pada tahun 2017 sebanyak 12 artikel terpublikasi.

3. Riset dianalisis sesuai dengan proses manajemen risiko dibagi menjadi Risk Identification, Risk Assessment, Risk Allocation dan Risk Mitigation. Dari 75 artikel yang dievaluasi, sebanyak 54,63\% (59 artikel) difokuskan pada identifikasi risiko.

4. Pendekatan kualitatif sebanyak 33 artikel (44\%) menjadi metodologi pilihan utama dan juga metode Survey/Questionare merupakan metode yang cukup mendominasi.

5. Berdasarkan hasil literature mengenai berbagai risiko proyek jalan tol di ASEAN dengan skema PPP, Hasil menunjukkan bahwa 10 faktor risiko yang paling banyak dilaporkan dalam literatur/ frekuensi tinggi adalah: Risiko Politik, Risiko Finansial, Risiko Desain, Konstruksi dan Uji Operasi, Risiko Operasi dan Pemeliharaan, Risiko Pendapatan, Risiko Force Majure, Risiko Lokasi, Risiko Kepemilikan Aset, Risiko Hubungan, dan Risiko Interface.

6. Saran untuk penelitian berikutnya adalah dengan menambah kata kunci pencarian dan memperluas pencarian selain di ASEAN. Dominasi pembahasan mengenai identifikasi risiko pada artikel paling sering menjadi topik, sedangkan mengenai mitigasi risiko masih jarang dijumpai sehingga dapat menjadi topik riset bagi peneliti selanjutnya.

\section{DAFTAR PUSTAKA}

Abdullah, N., Sufian, A., Asenova, D., \& Bailey, S. J. (2014). "PPP/PFI in Malaysian Development Plans: Purpose, structure, implementation, financing and risk transfer". Proceedings of 5th Asia-Pacific business research conference, February 2020, pp.: 1-14.

Ahmad, U., Ibrahim, Y., \& Minai, M. S. (2018). "Malaysian public-private partnerships: Risk management in build, lease, maintain and transfer projects". Cogent Business \& Management, Vol. 5, No. 1, November 2018. pp.: 1-6.

Alkaf, N., \& Karim, A. (2011). Risk Allocation in Public-Private Partnership (PPP) Project: A Review On Risk Factor. International Journal of Sustainable Construction Engineering \& Technology (ISSN: 2180-3242) Vol 2, Issue 2, 2(2).

ADB. (2011). Proposed Equity Contribution and Administration of ASEAN Infrastructure Fund. Asian Development Bank. Philippines.

Carbonara, N., Costantino, N., \& Pellegrino, R. (2014). "Revenue guarantee in public-private partnerships: a fair risk allocation model". Construction management and economics, Vol. 32, No. 4, October 2014, pp.: 403-415.

Carbonara, N., Costantino, N., Gunnigan, L., \& Pellegrino, R. (2015). "Risk management in motorway PPP projects: empirical-based guidelines". Transport Reviews, Vol. 35, No. 2, March 2015, pp.:162-182.

Chan, A. P., Yeung, J. F., Yu, C. C., Wang, S. Q., \& Ke, Y. (2011). "Empirical study of risk assessment and allocation of public-private partnership projects in China". Journal of management in engineering, Vol. 27, No. 3, July 2011, pp.: 136-148. 
Cheung, E., \& Chan, A. P. (2011). "Risk factors of public-private partnership projects in China: Comparison between the water, power, and transportation sectors". Journal of urban planning and development, Vol. 137, No. 4, April 2011, pp.: 409-415.

Chou, J. S., \& Pramudawardhani, D. (2015). "Cross-country comparisons of key drivers, critical success factors and risk allocation for public-private partnership projects". International Journal of Project Management, Vol. 33, No. 5, 2015, pp.: 11361150 .

Chung, D., \& Hensher, D. A. (2015). "Modelling risk perceptions of stakeholders in publicprivate partnership toll road contracts". Abacus, Vol. 51, No. 3, 2015, pp.: 437-483.

Debataraja, L. R., Suraji, A., \& Ophiyandri, T. (2020). "Analisis Risiko Investasi Infrastruktur Berbasis Fuzzy Analytical Hierarchy Process (F-AHP)". Jurnal Manajemen Aset Infrastruktur \& Fasilitas, Vol. 4, No. 2, April 2020. Hal: 121-132.

Durach, C. F., Kembro, J., \& Wieland, A. (2017). "A new paradigm for systematic literature reviews in supply chain management". Journal of Supply Chain Management, Vol. 53, No. 4, 2017, pp.: 67-85.

Emirullah, C., \& Azam, M. (2014). "Examining public private partnerships in ASEAN countries: The role of investment climate". Theoretical and applied economics, Vol. 21, No. 2, 2014, pp.: 67-76.

Grimsey, D., \& Lewis, M. K. (2005). “Are Public Private Partnerships value for money?: Evaluating alternative approaches and comparing academic and practitioner views". Accounting forum, Vol. 29, No. 4, 2005, pp.: 345-378.

Hwang, B. G., Zhao, X., \& Gay, M. J. S. (2013). "Public private partnership projects in Singapore: Factors, critical risks and preferred risk allocation from the perspective of contractors". International journal of project management, Vol. 31, No. 3, 2013, pp.: 424433.

Ke, Y., Wang, S., Chan, A. P., \& Cheung, E. (2009). "Research trend of public-private partnership in construction journals". Journal of construction engineering and management, Vol. 135, No. 10, 2009, pp.: 1076-1086.

Kingombe, C. (2011). "Achieving pro-poor growth through investment in rural feeder roads: the role of impact evaluation". Overseas Development Institute, Background Note, August 2011.

Kwak, Y. H., Chih, Y., \& Ibbs, C. W. (2009). "Towards a comprehensive understanding of public private partnerships for infrastructure development". California management review, Vol. 51, No. 2, 2009, pp.: 51-78.

Le, P. T., Kirytopoulos, K., Chileshe, N., \& Rameezdeen, R. (2019). "Taxonomy of risks in PPP transportation projects: a systematic literature review". International Journal of Construction Management, June 2019, pp.: 1-16.

Liu, J., Love, P. E., Davis, P. R., Smith, J., \& Regan, M. (2015). "Conceptual framework for the performance measurement of public-private partnerships". Journal of Infrastructure Systems, Vol. 21, No. 1, 2015, pp.: 1-15.

Likhitruangsilp, V., Do, S. T., \& Onishi, M. (2017). A Comparative Study on the Risk Perceptions of the Public and Private Sectors in Public-Private Partnership (PPP) Transportation Projects in Vietnam. Engineering Journal, 21(7), 213-231.

Mehrizi, H. Z., \& Bafqi, M. A. B. (2016). "Risk Assessment of Public Private Partnership Contract in Highway Project: A Comparison between Simple and Fuzzy Methods". Education and Training, Vol. 12, No. 3, 2016. pp.: $481-492$.

Mohd-Rahim, F. A., Abd-Rahim, M. S., Zainon, N., Chuing, L. S., \& Abd-Samad, Z. (2018). Project Life Cycle Risk of Public-Private Partnership (PPP) Projects for Construction Sustainability. Journal of Design and Built Environment, 39-53. 
Nguyen, A., Mollik, A., \& Chih, Y. Y. (2018). "Managing critical risks affecting the financial viability of public-private partnership projects: Case study of toll road projects in Vietnam". Journal of Construction Engineering and Management, Vol. 144, No. 12, 2018, pp.: 1-13.

Osei-Kyei, R., \& Chan, A. P. C. (2015). "Review of studies on the Critical Success Factors for Public-Private Partnership (PPP) projects from 1990 to 2013". International Journal of Project Management, Vol. 33, No. 6, 2015, pp.: 1335-1346.

Osei-Kyei, R., \& Chan, A. P. C. (2017). "Implementing public-private partnership (PPP) policy for public construction projects in Ghana: Critical success factors and policy implications". International Journal of Construction Management, Vol. 17, No. 2, 2017, pp.: 113-123.

Pellegrino, R., Vajdic, N., \& Carbonara, N. (2013). "Real option theory for risk mitigation in transport PPP". Built Environment Project and Asset Management, Vol. 3, No. 2, 2013, pp.: 199-213.

Sandhyavitri, A., \& Saputra, N. (2019). “Analisis Risiko Jalan Tol Tahap Pra Konstruksi (Studi Kasus Jalan Tol Pekan Baru-Dumai)”. Jurnal Teknik Sipil, Vol. 9, No. 1, 2019, Hal: 119.

Santoso, D. S., Joewono, T. B., Wibowo, A., Sinaga, H. P. A., \& Santosa, W. (2012). "PublicPrivate Partnerships for Tollway Construction and Operation: Risk Assessment and Allocation from the Perspective of Investors" Journal of Construction in Developing Countries, Vol. 17 No. 2, 2012, Hal: 41-62.

Sihombing, L. B. (2017). "Project finance and risk modeling using a system dynamics approach: A toll road project" Malaysian Journal of Industrial Technology, Vol. 2, No. 2, 2017, pp: 86-93.

Soemitro, R. A. A., \& Suprayitno, H. (2020). "Preliminary Reflection on Basic Problematics of National Public Infrastructure Financing in Indonesia". Journal of Infrastructure \& Facility Asset Management, Vol. 2, No. 1, 2020. pp: 51-62.

Suprayitno, H., \& Soemitro, R. A. A. (2018). "Preliminary Reflexion on Basic Principle of Infrastructure Asset Management". Jurnal Manajemen Aset Infrastruktur \& Fasilitas, Vol. 2, No. 1, 2018. Hal: 1-10.

Suseno, Y. H., Wibowo, M. A., \& Setiadji, B. H. (2015). "Risk Analysis of BOT Scheme on Post-construction Toll Road". Procedia Engineering, 125, 2015, pp: 117-123.

Sy, D. T., Likhitruangsilp, V., Onishi, M., \& Nguyen, P. T. (2016). "Impacts of risk factors on the performance of public-private partnership transportation projects in Vietnam" Munich Personal RePEc Archive, Vol. 5, No. 1, June 2016. pp.: 49-71.

Tang, L., Shen, Q., \& Cheng, E. W. L. (2010). "A review of studies on Public-Private Partnership projects in the construction industry". International Journal of Project Management, Vol. 28, No. 7, 2010, pp.: 683-694.

Tranfield, D., Denyer, D., \& Smart, P. (2003). Towards a methodology for developing evidence- informed management knowledge by means of systematic review. British journal of management, Vol. 14, No. 3, 2003, pp.: 207-222.

Tsai, C., \& Lydia Wen, M. (2005). "Research and trends in science education from 1998 to 2002: A content analysis of publication in selected journals". International Journal of Science Education, Vol. 27, No. 1, 2005, pp.: 3-14.

Valipour, A., Yahaya, N., Noor, N. M., Valipour, I., \& Tamošaitienè, J. (2019). “A SWARACOPRAS approach to the allocation of risk in water and sewerage public-private partnership projects in Malaysia”. International Journal of Strategic Property Management, Vol. 23, No. 4, 2019, pp.: 269-283. 
Wibowo, A., \& Alfen, H. W. (2015). "Government-led critical success factors in PPP infrastructure development". Built Environment Project and Asset Management, Vol. 5, No. 1, 2015, pp.: 121-134.

Yang, W., \& Dai, D. (2006). "Concession Decision Model of BOT Projects Based on a Real Options Approach”. International Conference on Management Science and Engineering 2006, pp. : 307-312.

Yu, Y., Chan, A. P. C., Chen, C., \& Darko, A. (2018). "Critical Risk Factors of Transnational Public-Private Partnership Projects: Literature Review". Journal of Infrastructure Systems, Vol. 24, No. 1, 2018, pp.: 1-11. 
(e)ISSN 2615-1847 (p)ISSN 2615-1839

Jurnal Manajemen Aset Infrastruktur \& Fasilitas - Vol.5, No.1, Januari 2021 